Article

\title{
Determinants of sustainable business model of companies early stage of development
}

\section{Marek Jabłoński *}

* The Department of Management, the University of Dąbrowa Górnicza (Wyższa Szkoła Biznesu w Dąbrowie Górniczej), Zygmunta Cieplaka Str. 1c, 41-300, Poland;

E-Mail: marek.jablonski@ottima-plus.com.pl, Tel. +48 604538566

\begin{abstract}
The paper presents the findings of research on companies in the early stage of development based on the concept of ensuring their sustainability. The starting point is attributes shaping a sustainable model of start-ups. A solution has been proposed and examined that identifies the factors dynamising a business model, which give the company the ability to make fast changes in the configuration of the business model, and that applies stabilizing factors based on the concept of the Triple Bottom Line. The research problem is a response to the phenomena of the bankruptcy of many start-ups that cannot find a way to survive in the long term. The business models of companies in the early stage of development should be designed taking into account the possibility of their dynamic and iterative changes when the earlier assumptions do not work when implemented in practice. A cognitive gap has been observed as the relevant literature does not propose a systemic solution to the problem of instability of the startups viewed from the perspective of the business model concept. The research problem, therefore, is to identify potential new methods to ensure the sustainability of young companies trying to combine aspects dynamising changes in business models, taking into account economic, environmental and social aspects. The findings of research on companies in the early stage of development show that when the methods of increasing the flexibility of the business model are applied and attention is drawn to environmental and social activities and a strong emphasis is put on financial performance, reflecting the expectations of shareholders, the concept of ensuring the sustainability of young companies from the point of view of sustainable business model attributes emerges.
\end{abstract}

Keywords: Startups, business model, sustainable business model, early stage of development, changes of business model, Triple Bottom Line.

\section{Introduction}

Business models of companies in early stages of development are exposed to many risks arising from their maladjustments to market expectations. Business models should have abilities to capture value from the market. In classical terms, the concept of sustainable management refers to the achievement of economic, ethical and environmental objectives. However, the managers of young companies in the early stage of development rarely think about the triad and the most important thing for them is to survive and achieve the expected success. The paper presents the concept of the combined use of real options theory and the Lean Startup method in the process of adapting the business model of companies in the early stage of development to achieve a sustainable business 
model status. It shows how to pivot the structure of business models. Assessing the ability to make dynamic changes in genotypes of business models may be an interesting topic of scientific exploration and practical implementations of the sustainable business model concept. The approach may contribute to the development of the sustainable business model concept, in particular for the companies in their early stage of development. The author wants to fill in the gap observed during the search for the factors determining the development of the business models of companies in the early stage of development in terms of a dynamic ability to modify the business model and following the principles of the "Triple Bottom Line" concept at the earliest possible stage of development. When this proposal is supported by the principles of the Triple Bottom Line, these opportunities can be expanded but the principles contained in this concept should be incorporated into the business model genotype. This combination will enhance the chances of survival of very young companies. The use of real options is important for flexible management of the startups development. The use of real options when making investment decisions, particularly in the process of initial development of a business model, can significantly increase the flexibility of the approach and neutralize uncertainty. The number of variables that affect the success or failure of a new business venture is so large that any method should be used to reduce business risk. The common use of the real options theory and the Lean Startup method can help managers to harness the factors determining the need to adapt the proposed business solution to market needs and ensure the possibility of creating shareholder value through the efficient and effective implementation of an innovative business model. The paper is structured as follows. After the introduction (Section 1), the discussion of sustainable management in business models (Section 2), young startup companies and their life cycle are discussed (Section 3). Section 3 deals with the Lean Startup method as a tool for implementing rules of a sustainable business model. This analysis provides the basis for a discussion of the thesis that making quick pivots in the business model according to the principles of the Lean Startup method increases management flexibility and opens new spaces to search features describing a sustainable business model of the company in the early stage of development. Section 4 deals with real options in business models. This section shows that the application of the real option theory in managing young companies could be considered as a new way of building sustainable business model assumptions. Section 5 presents the problem of the conceptualization of a sustainable business model for startups. It offers a proposal to make a business model flexible and focus on social responsibility issues, which should contribute to the survival of not only large companies but also of startups. This section shows that a sustainable business model is a model that reduces the risk of failure and enables the company to make changes quickly in order to achieve business goals, even if the initial assumptions have become significantly obsolete. Section 6 presents the objectives of research are described, which is based on qualitative and bibliographic research and research findings. Research covered the selected company listed on the NewConnect AIM in Warsaw, operating in the renewable energy sector. Finally, Section 7 presents the conclusions which summaries the core findings of the paper and the core results of analysis.

\section{Sustainable management in business models}

In the late 1990s, there were attempts at identification of business models and defining of performance measures describing them. The research in this field was done by A. Slywotzky with the team who described 22 profitable business models based on experiences of American companies. He 
paid attention to one of indicators of description of effectiveness of a business model; namely, the ratio of market value and turnover [1].

The component approach is of particular importance in the process of analysing business models since it is components that shape the business model configuration and they underlie their whole philosophy. Table 1 shows selected approaches to the division of the business model into components that are presented in the relevant literature. In this perspective, the business model configuration is essential, which, in the opinion of M. Jabłoński, is such a combination of carefully selected business model components that ensures an increase in company value in the given internal and external company environment. Theoretically, it can be assumed that a business model component should function only if it either directly contributes to the increase in the value and/or it is essential to ensure the consistency of the business model [2] (p. 398).

Table 1. Components shaping business models [3].

\begin{tabular}{|c|c|}
\hline Author & Specific components of business models \\
\hline Horowitz (1996) & Prize, product, distribution, characteristics of organization and technology. \\
\hline $\begin{array}{l}\text { Viscio and Pasternak } \\
\text { (1996) }\end{array}$ & Global competence, corporate governance, business units, services, connections of units. \\
\hline Timmers (1998) & $\begin{array}{l}\text { Product/service, flow of information, business actors and their roles, benefits for the actors, } \\
\text { sources of proceeds, marketing strategy. }\end{array}$ \\
\hline Markides (1999) & $\begin{array}{l}\text { Product innovations, relationships with customers, infrastructure management, financial } \\
\text { aspects. }\end{array}$ \\
\hline Donath (1999) & $\begin{array}{l}\text { Understanding of customer, marketing tactics, corporate governance, the Internet and } \\
\text { Intranet possibilities. }\end{array}$ \\
\hline Gordijn et. al. (2001) & $\begin{array}{l}\text { Actors, market segments, value offer, activity of value, network of stakeholders, interfaces of } \\
\text { values, changes of values. }\end{array}$ \\
\hline $\begin{array}{l}\text { Linder and Cantrell } \\
\text { (2001) }\end{array}$ & $\begin{array}{l}\text { Prize model, income model, model of business processes, online trade possibilities, } \\
\text { organizational forms, value offers. }\end{array}$ \\
\hline $\begin{array}{l}\text { Chesbrough and } \\
\text { Rosenbaum }(2000)\end{array}$ & $\begin{array}{l}\text { Value offer, market targets, structure of inner chain of values, structure of costs, profit } \\
\text { model, value network, competition strategy. }\end{array}$ \\
\hline Gartner (2003) & $\begin{array}{l}\text { Market offer, competences, investing in key technologies, annual net profit/loss (bottom } \\
\text { line). }\end{array}$ \\
\hline Hamel (2001) & Key strategy, strategic resources, value network, customer connections. \\
\hline Petrovic et. al. (2001) & $\begin{array}{l}\text { Model of values, model of resources, production model, model of relationships with } \\
\text { customers, income model, model of capital, market model. }\end{array}$ \\
\hline $\begin{array}{l}\text { Dubosson - Torbay et. } \\
\text { al. }(2001)\end{array}$ & $\begin{array}{l}\text { Products, relationships with customers, infrastructure and network of partners, financial } \\
\text { aspects. }\end{array}$ \\
\hline Afuah and Tucci (2001) & $\begin{array}{l}\text { Value for the customer, range, price, incomes, activity connections, implementation, } \\
\text { capabilities and balance. }\end{array}$ \\
\hline Weill and Tucci (2001) & $\begin{array}{l}\text { Strategic objectives, value offer, income sources, success factors, distribution channels, key } \\
\text { competences, customer segments, IT infrastructure. }\end{array}$ \\
\hline Applegate (2001) & Concept of capabilities and values. \\
\hline Amitt and Zott (2001) & Transaction contents, structure of transaction, corporate transactions. \\
\hline $\begin{array}{l}\text { Alt and Zimmerman } \\
(2001)\end{array}$ & Mission, structure, processes, incomes, compatibility with law, technologies. \\
\hline $\begin{array}{l}\text { Rayport and Jaworski } \\
(2001)\end{array}$ & Value cluster, market range of the offer, system of resources, financial model. \\
\hline Betz (2002) & Resources, sale, profit and capital. \\
\hline Magretta (2002) & Market objectives, value offer, costs, profits, customer benefits. \\
\hline $\begin{array}{l}\text { Von der Horst et. al. } \\
(2002)\end{array}$ & $\begin{array}{l}\text { Network of deliverers' value, value offer, capabilities and competences, support, } \\
\text { infrastructure, specific characteristics. }\end{array}$ \\
\hline Hogue (2002) & $\begin{array}{l}\text { Network of suppliers' value, market objectives, evaluation of resources, incomes, strategy, } \\
\text { courses of production/services processes, differentiation, mission, customer benefits, } \\
\text { environment, company identity, company reputation. }\end{array}$ \\
\hline Chesbrough (2003) & $\begin{array}{l}\text { Network of suppliers' value, market objectives, evaluation of resources, value offer, } \\
\text { competences and capabilities, costs, strategy. }\end{array}$ \\
\hline $\begin{array}{l}\text { Hedman and Kalling } \\
\text { (2003) }\end{array}$ & $\begin{array}{l}\text { Network of suppliers' value, evaluation of resources, value offer, capabilities and } \\
\text { competences, processes, competitiveness, initial offer }\end{array}$ \\
\hline
\end{tabular}




\begin{tabular}{|l|l|}
\hline $\begin{array}{l}\text { Osterwalder and Pigneur } \\
(2010)\end{array}$ & Design of business model components. \\
\hline Teece (2010) & $\begin{array}{l}\text { The essence of a business model is in defining the manner by which the enterprise delivers } \\
\text { value to customers, entices customers to pay for value, and converts those payments to profit }\end{array}$ \\
\hline
\end{tabular}

The presented components proposed by various authors show how the interdisciplinary nature includes the issue of business models. In such a holistic approach, the assumptions of sustainable management should be examined in the context of the business model.

The Sustainable Business Model concept is based on two pillars: First, the neoclassical economic paradigm is contrasted with sustainability concepts to formulate prescriptions for corporate sustainability. This concept was presented by F. Lüdeke-Freund [4], (p. 33). As proposed by W. Stubbs and C. Cocklin organizations adopting a Sustainable Business Model must develop internal structural and cultural capabilities to achieve firm-level sustainability and collaborate with key stakeholders to achieve sustainability for the system that an organization is part of [5]. In the relevant literature, several approaches to defining a sustainable business model can be distinguished.

There is no unambiguous definition and agreement about the concept of sustainability in the relevant literature. Various terms are used in different interpretations such as sustainability, business model sustainability, sustainability business model, sustainable business model, sustainable business, business case for sustainability. According to W. Stubbs and C. Cocklin, "Sustainability Business Model" is a model where sustainability concepts shape the driving force of the firm and its decision making [5]. According to S. Schaltegger and F. Lüdeke-Freund, a "Business Model For Sustainability" helps describing, analysing, managing, and communicating a company's sustainable value proposition to its customers, and all other stakeholders, how it creates and delivers this value, and how it captures economic value while maintaining or regenerating natural, social, and economic capital beyond its organizational boundaries [6]. This authors argue that extending the conventional view of a business model designed around a value proposition for customers, we acknowledge that no sustainable value can be created for customers without creating value to a broader range of stakeholders. A business is carried by a stakeholder network and - in spite of the fact that a business model is a market-oriented approach - particularly a business that contributes to sustainable development needs to create value to the whole range of stakeholders and the natural environment, beyond customers and shareholders. As regards the definition "Business Cases For Sustainability",

S. Schaltegger, F. Lüdeke-Freund, Erik G. Hansen point out that business cases for sustainability may be worthwhile to get from single and event-driven business cases for sustainability to business models for sustainability, which serve as templates for reproducing the respective business cases on a regular basis. In other words, moving from single to continuous business case creation may be supported by a business model rationale which positions sustainability as an integral part of the company's value proposition and value creation logic [7]. A sustainable approach to business provides a range of new possibilities of creating modern business models. A. Jabłoński defines a "Sustainable Business Model" in the context of building long-term value of a socially responsible company. It is the model built by the joint use of the corporate social responsibility and value based management concepts that ensures that the needs of shareholders and other stakeholder groups are fulfilled, through the skillful balancing of company's potential towards generating value allocated in a sustainable way, enabling continuity of company management. This is a holistic model [8], (p. 402). The approach proposed by the author is in line with the assumptions of the neoclassical paradigm in economics but with intensive pro-social and environmental activities for the purpose of long-term survival and development. W.M. Grudzewski, I.K. Hejduk, A. Sankowska and M. Wańtuchowicz argue that "Sustainability" is the ability to provide continuous learning, adaptation and development, 
revitalization, reconstruction, reorientation to maintain lasting and distinctive position in the market by offering buyers value today and in the future with an organic variation of constituting business models and the resulting creation of new opportunities and objectives and answers at balancing the interests of different groups [9]. In the literature, the issue of a Sustainable Business Model is usually examined taking into account economic, environmental and ethical factors, and it is the classical approach based on the assumptions of the Triple Bottom Line concept mentioned before, where a key characteristic is business sustainability. It is crucial to balance the areas related to financial, social and environmental factors to find a way of achieving business success in the long term. One hypothesis could be that a separation of the three areas makes sense at the operational level (i.e. keeping operative economic environmental and social responsibilities distinct), while a strategic decision would only be possible when considering the three dimensions simultaneously [10]. In the area of management science several leading trends related to the interpretation of the sustainability concept as outlined above can be seen. The leading works in this area may include the works of German scientists. Another approach to the issue of sustainability is an approach based on links between different ethical motivations and kinds of corporate social responsibility (CSR) activities that distinguish between different types of business cases with regard this sustainability. The design of CSR and corporate sustainability can be based on different ethical foundations and motivations. CSR is considered an area of management excellence and corporate sustainability as a management challenge to increase efficiency, quality and performance of the given processes and products. Efficiency gains, costs reductions and incremental process and product innovations are pursued. A broad range of business case drivers such as cost reduction, innovation (mainly incremental), brand value, or sales are addressed. Technical and organisational excellence is targeted with optimization projects, incentive programmes, crossdisciplinary employee teams and task forces. According to S. Schaltegger and R. Burritt this business case, although clearly contributing towards sustainable development, is limited in scope as it focuses on the corporate entity, its products and direct relationships. Furthermore, a responsible business case for sustainability is incremental as it is created from the logic of the existing operational and business model [11]. Sustainability management refers to approaches dealing with social, environmental, and economic issues in an integrated manner to transform organizations in a way that they contribute to the sustainable development of the economy and society, within the limits of the ecosystem [6]. Another look at the issue of the Sustainable Business Model is based on an innovative approach. The works developing this trend in the context of the business model concept may include the works by Schaltegger, S.; Lüdeke-Freund, F. \& Hansen, E. Boons, F.; Montalvo, C.; Quist, J. \& Wagner, M. [7],[12],[13]. According to F. Boons, C. Montalvo, J. Quist, M. Wagner, sustainable development requires radical and systemic innovations. Such innovations can be more effectively created and studied when building on the concept of business models. This concept provides firms with a holistic framework to envision and implement sustainable innovations. An important and interesting trend in research on the issue of the Sustainable Business Model is its financial implications. As they write A. Carroll and K. Shabana narrow view of the business case justifies CSR initiatives when they produce direct and clear links to firm financial performance. Mostly, the narrow view of the business case focuses on immediate cost savings. By contrast, the broad view of the business case justifies CSR initiatives when they produce direct and indirect links to firm performance [14]. The approach to business models from the point of view of the Sustainable Competitive Advantage concept has been proposed by M. Morris, M. Schindehutte. and J. Allen, who argue that the business model is a concise representation of how an interrelated set of decision variables in the areas of venture strategy, 
architecture and economics are addressed to create sustainable competitive advantage in defined markets [3], (p. 727).

On the other hand, an approach based on an analysis of business cases focused on the principles of sustainable business contributes to increasing value for shareholders.

To create a business case for sustainability requires strategic management to identify, create and strengthen the links between non-monetary social and environmental activities on the one hand and business or economic success on the other hand. Furthermore, in order to achieve such business cases the formulation and implementation of corporate strategies have to change, compared to strategies that only strive for "market sustainability" through competitive advantages in the sense of the resource based theory of the firm. That is, strategic objectives and measures, and sometimes even the business model of a firm, have to be oriented towards a Triple Bottom Line [15]. Based on these key assumptions one can ask how strategic sustainability management can contribute to creating and managing business cases for sustainability, what drivers it has to address in order to create a business case for sustainability, and how business model innovation can serve as a framework for this endeavour.

The drivers of a business case for sustainability are variables which directly influence economic success and therefore are related to the drivers of a conventional business case for an overview of performance drivers. However, the links between voluntary sustainability activities and economic success are often different and therefore also the kind of influence a social or environmental activity has on the economic drivers. Among the core drivers of a business case for sustainability are:

- Costs and cost reduction.

- Sales and profit margin.

- Risk and risk reduction.

- Reputation and brand value.

- Attractiveness as employer.

- Innovative capabilities [16], (p. 7-10).

According to D. Hutchinson, J. Singh, K. Walker factors shaping a sustainable business approach may include elements such as: the natural environment, driving forces, purchasing policies, value adding processes, intermediaries and transport, retail practices, marketplace/society. [17] To achieve the effect of sustainability, it is important to apply strategic thinking focused on this approach in the organization. Sustainable business thinking is a holistic approach to thinking about business that seeks to integrate consideration of the three dimensions of sustainability - social, environmental and economic-in a manner that balances or aligns value creation for all stakeholders including the environment and society at all levels and through all activities of the business. This approach was presented by N.M.P. Bocken, P. Rana, S.W. Short, [18], (p. 77).

\section{Young startup companies and their life cycle.}

Young companies determine the vitality of economies. The growth rate of the emergence of creative companies is an indicator of market growth potential and improving macroeconomic indicators. Many research centers deal with the issue of startups, among others, the following works can be distinguished: N. Chruchill, V. Lewis [19], J. Eggers, L. Lehey, N. Churchill [20], S.H. Hanks, C.J. Watson [21], R. Nanda \& M. Rhodes-Kropf [22], M. Scott, R. Bruce [23], Y. Paik, \& H. Woo, [24], I. Adizes [25]. 
According to S. Blank and B. Dorf, startup is a temporary organization dedicated to looking for a scalable, repeatable and profitable business model [26], (p. 19). Such a definition clearly indicates the startup characteristics such as:

1. Temporality.

2. Lack of durability

3. Volatility.

4. Risk and uncertainty.

With reference to the life cycle of young companies, A. Damodaran defines the following features: no history, little or low revenue and operating losses, strong dependence on investment funds, many of them do not survive, high liabilities compared to the raised capital, investments are not liquid [27], (p. 5-6).

Figure 1 shows the early stages of the life cycle of companies.

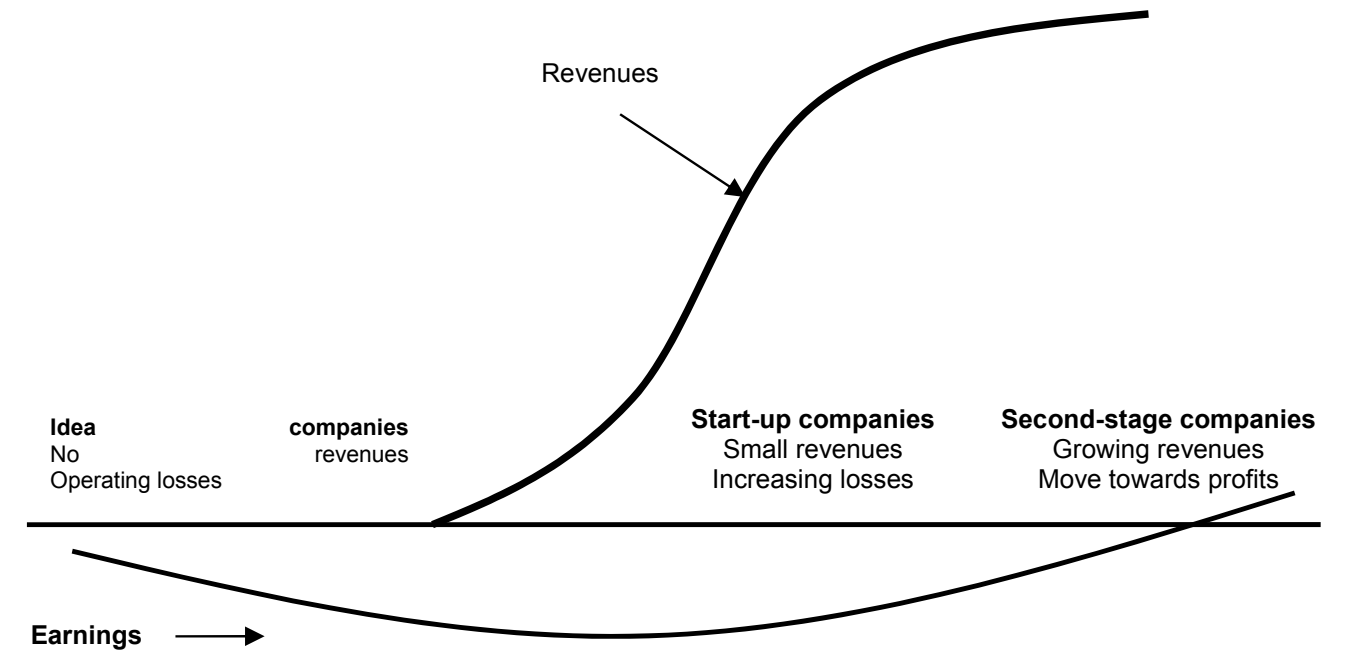

Figure 1. The Early Stages of the Life Cycle created by A. Damodaran [27], (p. 4).

The first stage is a business idea characterized by a lack of revenues and operating losses. While a startup is being built revenues grow and in the second stage, revenues increase dynamically, which enhances profits. This cycle occurs in real conditions very quickly. After the first stage, some companies of this type may sometimes feel the need to modify the business model, when the signals from the market confirm the credibility of variables determining a need to verify the idea with reference to the dynamically changing customer preferences. Young companies are particularly exposed to rapid bankruptcy. Based on the data from the US market, it is clear that only one third of companies operating in the public and private sectors survived after seven years of their activity. Better results are achieved only by companies in the health and financial services sector. Companies operating in sectors related to new technologies have a big share in bankruptcies. Only $24 \%$ of companies, so one fourth of those operating in the IT sector survived in the market in the studied period [28], (p. 6].

It should be noted that in startup organizations not only the strategy will determine its success but a well designed business model based on credible premises. The data presented lead to the conclusion that there is a need to seek solutions in the sphere of the problem of young companies sustainability, including the methods for developing a sustainable business model. Therefore, in both theory and practice of management optimal methods for ensuring the sustainability and success of startups are sought. 
S. Blank shows a Lean Startup as a new approach to designing startup organizations, believing that the startup founders should not begin by developing a business plan, but by searching a business model [28], (p. 7).

A management concept proposed in the relevant literature that focuses on the search for effective and efficient startup management methods is the Lean Startup method. Its assumptions are that the business and marketing functions of a startup should be treated in the same way as product development, so they deserve an equally systematic management methodology [31]. It is therefore necessary to focus attention on the new way of dealing with startups in order to achieve a higher level of concentration and draw attention to the new areas of starting business ventures.

S. Blank shows the principles of the Lean approach:

- Business model as a carrier of hypotheses,

- Customer development - Leaving the office to test the hypotheses,

- Agile development - Developing a product iteratively and incrementally,

- Evaluation of customer's needs and agile development teams - Hiring employees in order to learn, agility and speed,

- The data that are relevant - Customer acquisition costs and time of delivering value to the customer,

- Expected - Determining iterative ideas and evaluation with reference to those which are affected by them,

- Rapid - Work based on data that are good enough. [29], (p. 7).

The presented new approach is a kind of revolution in perceiving the process of marketing new business ventures and its features are being discussed and it triggers a new way of thinking about business startups. This shows that the existing management theories and practices are not quite suited for this type of company. Therefore, it is necessary to look for new ways of managing them. At the very beginning of its existence, a startup is in its essence a big unknown resulting from such exemplary variables as uncertain legal conditions for the functioning of the proposed solution, a product or service has not been tested yet, the solution is very often so innovative that preliminary tests do not prove that the solution will be able to generate the expected value in the future, the idea is based on not fully tested technologies, or these technologies are yet to be developed, the structure of customers and markets and the adaptation of internal structures to the range of offered value, etc. are not exactly known. A startup is basically a synonym for a business model that is maturing, changing, adapting to the interfaces with the dynamic external environment, experimenting and making mistakes but in itself, it has a potential to multiply the capital invested by investors in favourable circumstances. The assumption of startup activity is universal, regardless of industry, the idea going beyond the existing solutions can arise and sometimes in the form of a ground-breaking innovation change the entire sector. Testing the startup and as a result learning is used to find a scalable business model that enables the company to achieve the expected return. It should be noted that the fourth assumption of the Lean Startup method described above includes an alternative system of business decision-making. This is where there is a need to obtain information that will help determine whether you should continue in existing activities, or make a turn. Such an approach to startup management is consistent with the real options theory. While at this stage business venture should be assessed in terms of risk, there is justification for using real options for this purpose (the option is abandon, the option to expand, the option to contract, the option to defer, and the option to switch). Combining a flexible approach with the dynamic adjustment of the business model in its life cycle can be supported effectively by financial 
engineering based on the real options theory. The fifth assumption concerns the use of the assumptions of the Performance Management concept adapted to the specific character of startup companies. It is justified to identify the measurement needs for individual attributes and the functionality of the business model.

According to E. Ries, the wrong approach to creating a startup organization has been particularly noticeable in recent years. In the earlier epochs, the strategy and business plan were the reason for the likely success. Thus, the temptation is enormous to use them also for startups, but it does not work because the companies operate with too much uncertainty. A startup does not know yet who their customers will be or what the product should be like. Old management methods do not work. Planning and forecasting are accurate only if they are based on long-term assumptions, and today, they are difficult to predict [29] (p. 19). A business plan is often a key barrier to success. The managers implementing the previously developed assumptions of the business plan uncritically may omit a number of important issues arising from the volatility of markets and customer needs. The presented approach emphasizes the need for iterative adaptation of the company business model based on an analytical approach to the assessment of achievements and progress in the process of marketing a new startup company. The precursors of this approach point to the fact that the problem is that startups use tools effective for companies that have already found their business model, while a startup as a whole is reduced to what is unknown. In fact, a startup is a number of unproven hypotheses [30], (p. 27). A business model and the Lean Startup method play a key role in this new concept. According to E. Ries, one of the propagators of this concept, this method was designed for entrepreneurs and people who assess their actions. These are mostly investors - capital providers who risk, being convinced of the business model. E. Ries defines five principles of Lean Startup:

1. Entrepreneurs are everywhere - a startup consists in the fact that new products and services are developed in conditions of extreme uncertainty. This model is universal and can be used in companies of all sizes and in all industries and sectors.

2. Both entrepreneurship and management have to be considered - a startup is an institution and is not limited solely to the product, and therefore it requires a new management model, prepared for use in conditions of extreme uncertainty.

3. The process of verified learning - startups are not established just to produce something, earn money and serve customers. They are founded to learn how to build a profitable company. This learning process takes place in the course of numerous experiments that allow entrepreneurs to test individual elements of their vision.

4. Creation - measurements - learning - the core activity of a startup is to turn the ideas into finished products, observation and measurement of customer response and obtaining information that will help determine whether you should continue the activities, or make a turn. The processes of startups should be designed in such a way as to increase the speed of the feedback loop.

5. Innovative accounting - in order to enhance the performance of entrepreneurs and assess innovators based on their actions, it is necessary to focus on ways of monitoring progress, setting intermediate objectives and scheduling tasks. This requires a completely new type of accounting, created for startups and people who assess their actions.

The strategy of the organization is important but the success of startups is determined in particular by the business model and it should be monitored and changed dynamically. 


\section{Real options in business models}

The success of the business model largely depends on the scalability of the technology and services used. This is due to the fact that a common business environment is the Internet and social communication system. According to M. Morris, M. Schindehutte and J. Allen, it is possible to envision a business model life cycle involving periods of specification, refinement, adaptation, revision, and reformulation. An initial period during which the model is fairly informal or implicit is followed by a process of trial and error, and a number of core decisions are made that delimit the directions in which the firm can evolve [3], (p. 733). To this end, it is reasonable to apply the real options theory. The works by authors such as: Kulatilaka 1993 [30], T. Copeland 2001 [31], Trigeorgis 1996 [32], Myers 2001 [33], R. Adner [34], T. Copeland, T. Koller, J. Murrin [35] have contributed to the development of the real options issue. The behavioral theory which is connected with real options theory was developed by R. Cyert and J. March [36].

The most famous creator and promoter of the real options theory is L. Trigeorgis [37]. His classification is as follows:

- The option to defer (or option to wait);

- The option to alter the operating scale (i.e. to expand or contract);

- The time-to-build option (or option to stage);

- The option to abandon;

- The option to switch (outputs or inputs), and the growth option.

Real options in business models are often options present in strategic technology ventures, where profit is fully dependent on the creation of new technologies and their specific attributes. An approach based on the real options theory links the budgeting processes and strategic decision-making methodology. As a result, business flexibility greater than normal is often achieved. Technological business models easily fit in the principles of the real options methodology in the natural way. The planned strategic scenarios are based mainly on a technological approach to planning variants described by real options. The Real Options Valuation (ROV) method is particularly useful for the valuation of companies that are characterized by several rounds of investment and the high degree of uncertainty about the future, while profits can fluctuate from bankruptcy to potentially high return, if the industry develops successfully, and the company has reached a leading position. The concept of real options is based on the common use of DCF method assumptions and techniques of decision analysis that are important, for example in the process of selling. Venture Capital Funds divide investments into several sequences, inter alia just to motivate the management boards of companies to achieve specific goals, making their achievement conditional for further rounds of investment. Dividing the investment into several sequences, an investor greatly reduces risk, waiting with giving more money until he or she obtains specific information [38], (p. 132-133). From a theoretical point of view, options are attractive also because of the way of thinking about flexibility possible to achieve in many investment projects. However, applying the methodology in practice is difficult as it encounters many difficulties which can lead to erroneous conclusions. The complexity of the approach to options can also be a critical barrier to the use of the solution. These practical difficulties explain the limited use of the real options theory in analyses and strategic planning. Such an approach presented by E.H. Bowman, G.T. Moskowitz [39], (p. 776).

According to W. Patena, however, in fact every project can be valued by means of the real options methodology, if only it includes the possibility of some flexibility (available for project managers), for 
example, to abandon the project, postpone its implementation or make changes in the course of the project. In conclusion, almost any company can be regarded as a collection of real options [40], (p. 242). The inclusion of a new framework for the valuation of startup companies may introduce optimism resulting from entrepreneurship and include flexibility in the process of estimating and managing value. A key area of option valuation is to understand their meaning, especially when we deal with innovative startup companies, where it is essential to consider the nature of research and development that will be included in the company activities, which is required in the first years of company operation. The flexibility of this method is crucial here as the discounted cash flow approach to startups evaluation simply is usually not sufficient [41] (p. 20).

In this approach, the business model will be an important point of reference and the object which is subject to change depending on proposed real options. Further business model components can be seen as optional and that can be exchanged for others or got rid of altogether. Like financial options, all such phenomena can be called real options. If the investment opportunities include real possibilities, it is important to take into account their value. Therefore, in determining the financial viability of a business model that has real potential, it is necessary to take into account value of these options. According to D. Kundish and T. John rather than develop theoretical details of the valuation, it is possible to show how the optionality can be integrated with BMR (business model of representation) and how the considered options may have an impact on the financial condition estimated for a specific business model [42] (p. 4456). As regards the relationship between real options and corporate strategies, interesting results of the analyses have been presented by T. Wiśniewski and M. Pawlak. In addition to the favourable conditions for the use of real options in the corporate strategies, the attitude of executives and implemented vision of the future are important for their suitability. If the company wants to decide about the future of the sector, when it should take into account the uncertain future factors and the behaviour of competitors, real options become a natural tool to support decisionmaking. Strategies of market-leading companies are usually capital-consuming, and they tend to be based on innovative, highly risky solutions. It is particularly important to notice alternative scenarios for development and designing possible reactions to their occurrence [43], (p. 583). It is also possible to combine the philosophy of real options with the method of measuring and monitoring achievements, e.g. by means of the Balanced Scorecard. Final decisions should be made by managers on the basis of specific compromises, which are relevant to the current economic conditions [44], (p. 53-58). For each scenario of options, a dedicated map of a strategy can be prepared that reflects the actual way of the dynamic decision-making while maintaining the flexibility of strategic change.

As K. Obłój shows in relation to the application of the real options theory in strategic management:

1. In the conditions of extreme uncertainty, rational strategies that have a form of the set of realistic options can be built.

2. Different types of real options will have different value for different organizations, depending on the specific situation in the environment, as well as the resources, skills and history of the organization.

3. Thinking about the strategy in terms of the sequences of real options helps to assess the correctness of the direction and volume of strategic investments better than traditional budgeting tools.

Real options take better into account the fact that:

- probabilities and forecasts change their value over time.

- the changeability of the situation can rapidly affect the value of the undertaking and the value of options - both negatively and positively. 
- it is not enough to create value in the market, but it is still necessary to build the mechanism of its appropriation, and its effectiveness is not obvious at the moment of strategic undertakings,

- there may be many decision-making moments, and the pace of learning by the company and its resources change the chances of success and failures [45], (p. 175-181 and 194-195).

C. Krychowski highlights the issue of using real options in designing the business models. He believes that the relevant literature stresses the high degree of business model uncertainty. An innovator does not know from the beginning what the effect of the proposed business model will be. Therefore, it is reasonable to use real options. The main benefit of real options compared to conventional tools for strategic investment valuation, such as NPV (Net Present Value) and other methods based on the DCF (Discount Cash Flow) method is the possibility of assessing which investment projects may be better suited to the economic situation and are more flexible. Real options make it possible to combine the strategic plans and financial analysis. Also, it is better to understand why some large projects are undertaken for "strategic" reasons, despite the negative NPV and viceversa [46], (p. 6). This reasoning can be applied in the context of the design and development of business models, especially for startups, whose development scenarios can dynamically change due to uncertain boundary assumptions and future cash flows difficult to predict. Then particular problems arise in assessing their value. The logic of the real options method is based on the assumption that future investment and development opportunities depend on previous investment decisions. The company's development is seen as a sequence of decisions. Emphasizing the sequencing and possibility of introducing successive adjustments in the process of capital budgeting (or more broadly, in the process of company development) as opposed to analysing certain decisions as "now or never" solutions is - according to proponents of this method - the essence of the difference between using real options and DCF ( and other methods based on discounting the expected cash flows) [47], (p. 189).

The use of real options allows, within entrepreneurial processes, for the transformation of innovative ideas into profitable ventures. The appearance of options for the company will, in particular, build new and strategic competence so that the options could be used [48], (p. 387).

Although the real options theory derives from the theory of finance, it is in some ways very similar to the assumptions of the Lean Startup method. A common point that is reflected on the plane of the business model issue is decision-making flexibility, which contributes to learning opportunities in subsequent stages of the investment process. If the investment in the business model is treated as a project that never ends, pivot management as part of the Lean Startup approach will fill the area of the real options theory, which so far has not been part of operational management but of the analytical process used in the process of company valuation or other decision-making situations. The flexibility of the business model achieved using the assumptions of the real options theory and the Lean Startup method increases the investment attractiveness of startups.

\section{The conceptualization of sustainable business model for startups}

The dynamic testing of strategic hypotheses as an attribute of the Lean Startup method relates in particular to verifying business models. Making changes in the business model configuration vis-a-vis the base model, for which the decision has been made to invest in a business venture, is recommended in this approach. This is accomplished by making strategic pivots that navigate the business model towards achieving the ability to capture value from the market. In the process of designing the business 
model, the best idea is to think in the earliest stage of the process in terms of opportunities to make future modifications and also, if it is justified, to reconstruct the business model, if the project does not meet expected goals. Incorporating the maximum number of real options into the business model is favourable to making effective turns towards providing the expected return on investment.

Flexibility is a factor that plays a stabilizing function of business models in the early stage of development. The purpose of a startup is first and foremost to survive and ultimately achieve market success. Making dynamic changes in the business model skillfully contributes to achieving business goals. The process of adjusting the business model to the ability to create value for shareholders takes place. The sustainability of startup business is a set of business model components making up a consistent configuration with the maximum number of potential real options around it that make it possible to make quick strategic turns when the business model does not capture value from the market in a given situation. Sustainable Business Model considered from the point of view of the companies early stages of development should be based on the search for such a combination of factors boosting and stabilizing business operations, which provides the scalability, flexibility and agility organizations with strong support positive attitude to business stakeholders. Balance is a key axis around which revolves business activity of the company. Flexibility and agility should be the result of a large number of possible strategic options for the use of a dynamic development of the company. Sustainability should be based on conduct by the management of a dynamic dialogue with the different groups of stakeholders (investors, employees, customers, business partners, and others) at the same time strengthening their strategic support in areas related to the development directions of enterprise. The number of strategic options increases flexibility and agility of the company especially for the ability to survive. Hence the Sustainability for business models understand in this case, on the one hand the as ability to balance action various groups of stakeholders, and on the other hand, the ability of companies to survive in a very difficult market conditions in the initial phase. Incorporating additional real options that can be implemented in the future into the business model increases company value on the one hand, but on the other hand, it favours the rapid reconstruction of the base model. This state increases the investment attractiveness of the company, whose primary attribute is the flexibility of the business model thanks to the options in its configuration. Based on the literature and own findings, I propose the following definition of a sustainable business model for a startup. It is a set of characteristics determining a business model, based on the joint implementation of the assumptions of the real options theory, flexible testing of potential hypotheses and a dialogue with stakeholders that will ensure the survival of a startup and help it to turn into a successful company. According to this interpretation, a sustainable business model helps the company to survive and increases its investment attractiveness as it makes a decision-making process easier and reduces business risk, Figure 2. 


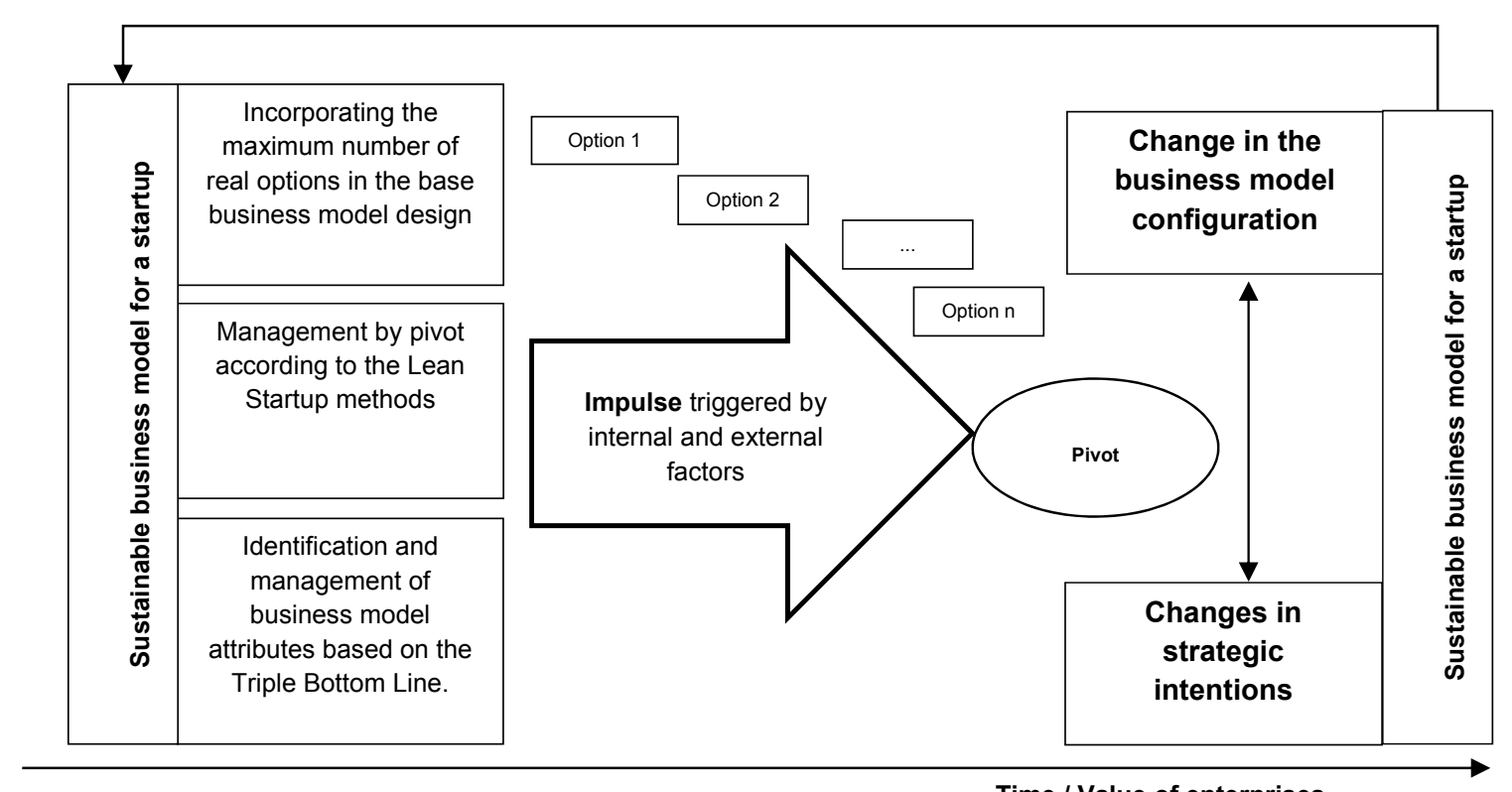

Time / Value of enterprises

Figure 2. The rationale for developing assumptions of a sustainable business model for startups.

Figure 2 shows the author's interpretation of a sustainable business model for startups.

While business is conducted, circumstances may occur that force managers to make changes in the configuration of business models. The value of the company also changes. In order to develop the features of a sustainable business model, a company should try to incorporate the maximum number of real options into its configuration at the stage of designing the business model. In the case of an impulse caused by internal and external factors, startups managers should quickly reconstruct the business model configuration and make changes in the strategic intentions, taking advantage of the opportunities inherent in the potential of options possible to apply. Therefore, a sustainable business model is a model that reduces the risk of failure and enables the company to make changes quickly in order to achieve business goals, even if the initial assumptions have become significantly obsolete.. A business model can be stabilized by applying the principles of the Triple Bottom Line, conducting an active dialogue with stakeholders and applying the principles of Corporate Governance in relation to the tasks of information policy towards stakeholders, especially investors.

\section{The methodology of research}

Research was based on the principles of qualitative research supported by bibliographic research. The qualitative research used the proposal by J.W Creswell, which is based on the following assumptions:

- Decide if theory is to be used in the qualitative proposal.

- If it is to be used, then identify how the theory will be used in study, such as an end point, or as a transformative - advocacy lens.

- Locate theory in the proposal early in study or at the end [49].

The purpose of research was to identify the characteristics of young companies with a clear focus on a survival factor. Research was conducted on a sample of four companies, which were selected for the study and are listed on the NewConnect AIM in Warsaw and operate in the renewable energy sector. 
Due to the uncertainty in terms of the stabilization of legal requirements, this sector in Poland generates high risk for the designed business models. These companies were able to survive in these difficult conditions, and even move to the stage of development and growth. The scope of research included:

a) Review of the literature on business models, startups, the real options theory and the assumptions of the Lean Startup method as an approach to the strategy of the survival of young companies.

b) Analysis of business models of companies in the early stage of development in terms of the implementation of the strategy of survival and development based on information documents and periodic reports.

c) Identification of qualitative factors that determine the possibilities of survival of young companies in the context of their incorporation into the business model structure, shaping a sustainable business model.

d) Finding such a configuration of tools of managing companies in the early stage of development that will apply to the attributes of the business model, giving it the ability to survive.

It should be noted that two key assumptions have been adopted in the paper:

a) A sustainable startup is an agile and flexible company, which has strategic options incorporated into its business model that it could use when needed. This is a company that monitors its business model by formulating strategic hypotheses verifying the effectiveness and efficiency of the business model.

b) A sustainable startup is a company that applies the principles of the Triple Bottom Line (balances the economic, environmental and social objectives) at the earliest possible stage of development, conducting a dialogue with different groups of stakeholders.

Research aimed to prove whether the dynamic adaptation of the business model to the changeability of the environment and balancing economic, environmental and social objectives can be favourable to the survival of a company in the early stage of development and whether it is possible to fulfil both of these conditions by implementing the strategy of survival.

With reference to the research problem, two research hypotheses have been formulated:

Hypothesis 1. A condition for the survival of the company in the early stage of development is to incorporate the maximum number of real options into the business model and thus its ability to dynamically change with the help of the methodology of testing strategic hypothesis is developed.

Hypothesis 2. A necessary condition for the survival of the company in the early stage of development is to use the assumptions of the Triple Bottom Line concept in such a way that they are applied as soon as possible in the life cycle of the organization.

In this way, it is possible to shape the assumptions of a sustainable business model of companies in the early stage of development based on the attributes characterizing the ability of a business model to change dynamically and a strategy of balancing goals towards the different groups of stakeholders.

Table 2 shows the selected companies listed on the NewConnect market operating in the renewable energy sector, whose business models are based on the ability to change and an emphasis on applying the principles of the Triple Bottom Line. The presented companies were forced to seek and implement various strategic options due to high uncertainty resulting from the instability of legislation in the field of renewable energy sources.

Table 2. Selected companies listed on the NewConnect AIM. 


\begin{tabular}{|c|l|l|}
\hline No. & Type of renewable energy & Companies listed on the NewConnect AIM in Warsaw \\
\hline 1. & Photovoltaic systems & Sunex S.A. \\
\hline 2. & Hydropower plants & $\begin{array}{l}\text { MVA Green Energy S.A, Automatyka Pomiary Sterowanie } \\
\text { S.A., Genesis Energy S.A. }\end{array}$ \\
\hline 3. & Biomass Co-firing & Fluid S.A, \\
\hline 4. & Biogas & BGE S.A, Esperotia Energy Investment S.A, \\
\hline
\end{tabular}

Qualitative research based on information documents and periodic reports covered the parameters that were considered the determinants of sustainability of the business models of companies in the early stage of development. These parameters were divided into two categories namely: Parameters dynamising a business model and parameters stabilizing a business model. Both groups of these parameters are responsible for ensuring the sustainability of the business model.

\section{Parameters dynamising a business model}

1. The number of strategic options incorporated into the business model possible to implement

2. Strategic scenarios presented in development strategies, which are the basis for testing strategic hypotheses.

3. The ability to change the configuration of the business model and the direction of company's development

\section{Parameters stabilizing a business model:}

1. Incorporating the principles of the Triple Bottom Line (economic, social and environmental factors) into the business model

2. Identifying the needs of stakeholders

3. Identifying the principles of Corporate Governance appropriate for companies in the early stage of development

Using three dynamising and three stabilizing factors related to the business model determines the assumption of the proposed concept of ensuring the sustainability of companies in the early stage of development.

Dynamising factors stem from the theoretical assumptions of the real options theory, Lean startup and a configuration approach to business models. Stabilizing factors derive from the the Triple Bottom Line concept and the concepts of Stakeholders and Corporate Governance. A review of relevant literature and the strategic context of operation of companies in the early stage of development are presented in the following sections.

\section{Research findings}

Research covered four selected companies listed on the NewConnect AIM in Warsaw operating in the renewable energy sector. Qualitative research based on secondary data was conducted with the use of records assessment contained in public information documents and periodic reports. The research findings are shown in table 3 . Research relates to the joint consideration of factors arising from the dynamics of the company operation in terms of a flexible business model based on using alternative strategic options, testing strategic hypotheses related to changing strategic scenarios according to the Lean Startup method and the principles of the Triple Bottom Line, corporate governance principles adequate for the NewConnect alternative market and dialogue with stakeholders. 
Table 3. Findings of research on selected companies on the NewConnect AIM.

\begin{tabular}{|c|c|c|c|c|}
\hline \multirow[t]{2}{*}{ Tested parameter } & \multicolumn{4}{|c|}{ Companies } \\
\hline & $\begin{array}{c}\text { Company } 1 \\
\text { (Biogas plants) }\end{array}$ & \begin{tabular}{|c|} 
Company 2 \\
(Agricultural biogas \\
plants)
\end{tabular} & $\begin{array}{l}\text { Company } 3 \\
\text { (Biomass co-firing) }\end{array}$ & $\begin{array}{c}\text { Company } 4 \\
\text { (Photovoltaic } \\
\text { systems) } \\
\end{array}$ \\
\hline \multicolumn{5}{|c|}{ Parameters dynamising a business model } \\
\hline $\begin{array}{l}\text { The number of } \\
\text { strategic options } \\
\text { incorporated into the } \\
\text { business model } \\
\text { possible to implement }\end{array}$ & $\begin{array}{l}\text { Two strategic } \\
\text { options: } \\
\text { 1. Expanding the } \\
\text { scale of } \\
\text { operations by } \\
\text { implementing } \\
\text { further biogas } \\
\text { projects, both } \\
\text { under own aegis } \\
\text { and under the } \\
\text { aegis of energy } \\
\text { partners } \\
\text { In the case of } \\
\text { own biogas } \\
\text { plants, sell } \\
\text { electricity. }\end{array}$ & $\begin{array}{l}\text { Four strategic options: } \\
\text { 1. Expanding the scale } \\
\text { of operation in the } \\
\text { production of } \\
\text { electricity and } \\
\text { thermal energy. } \\
\text { 2. Diversifying the } \\
\text { conducted activity- } \\
\text { as a substitute } \\
\text { investor for various } \\
\text { entities and a } \\
\text { broker in selling } \\
\text { electricity to own } \\
\text { project companies. } \\
\text { The expansion of } \\
\text { activities outside } \\
\text { the home country. } \\
\text { Biomass sales. }\end{array}$ & $\begin{array}{l}\text { Two strategic } \\
\text { options: } \\
\text { 1. Expanding the } \\
\text { scale of the } \\
\text { production by } \\
\text { producing } \\
\text { biochar. } \\
\text { 2. Scientific } \\
\text { research. }\end{array}$ & $\begin{array}{l}\text { Three strategic } \\
\text { options: } \\
\text { 1. Expanding the } \\
\text { scale of operation } \\
\text { outside the home } \\
\text { country } \\
\text { 2. Product } \\
\text { diversification - } \\
\text { selling and } \\
\text { assembling solar } \\
\text { systems. } \\
\text { Option of entering } \\
\text { into cooperation } \\
\text { with other } \\
\text { companies. }\end{array}$ \\
\hline $\begin{array}{l}\text { Strategic scenarios } \\
\text { presented in the } \\
\text { development } \\
\text { strategies which are } \\
\text { the basis for testing } \\
\text { strategic hypotheses. }\end{array}$ & $\begin{array}{l}\text { One scenario based } \\
\text { on the strategy of } \\
\text { expanding the scale } \\
\text { of operations. }\end{array}$ & $\begin{array}{l}\text { Two scenarios based on } \\
\text { expanding the scale of } \\
\text { operation and testing } \\
\text { strategic hypotheses in } \\
\text { the field of product } \\
\text { diversification. }\end{array}$ & $\begin{array}{l}\text { Two scenarios based } \\
\text { on expanding the } \\
\text { scale of operation } \\
\text { and testing strategic } \\
\text { hypotheses in the } \\
\text { field of product } \\
\text { diversification. }\end{array}$ & $\begin{array}{l}\text { Three strategic } \\
\text { scenarios for which } \\
\text { strategic hypotheses } \\
\text { are tested in the field } \\
\text { of foreign operation, } \\
\text { product diversification } \\
\text { and cooperation with } \\
\text { other companies in the } \\
\text { form of alliances, } \\
\text { mergers and } \\
\text { acquisitions. }\end{array}$ \\
\hline $\begin{array}{l}\text { The ability to change } \\
\text { the configuration of } \\
\text { the business model } \\
\text { and the direction of } \\
\text { company's } \\
\text { development. }\end{array}$ & $\begin{array}{l}\text { The ability to change } \\
\text { a business model due } \\
\text { to the availability of } \\
\text { resources, appropriate } \\
\text { technology. }\end{array}$ & $\begin{array}{l}\text { The ability to change a } \\
\text { business model based } \\
\text { on high-quality } \\
\text { competencies of } \\
\text { managers and relational } \\
\text { capital. }\end{array}$ & $\begin{array}{l}\text { The ability to } \\
\text { change the } \\
\text { configuration of the } \\
\text { business model in } \\
\text { the context of the } \\
\text { changing regulations } \\
\text { in the sector of } \\
\text { renewable energy } \\
\text { sources, resulting, } \\
\text { inter alia, from the } \\
\text { need to } \\
\text { adjust domestic } \\
\text { regulations to the } \\
\text { standards of } \\
\text { European Union } \\
\text { law. }\end{array}$ & $\begin{array}{l}\text { The ability to change a } \\
\text { business model based } \\
\text { on high-quality } \\
\text { competencies of and } \\
\text { managers capital, as } \\
\text { relational al } \\
\text { well as flexibility in } \\
\text { product sales. }\end{array}$ \\
\hline \multicolumn{5}{|c|}{ Parameters stabilizing a business model } \\
\hline $\begin{array}{l}\text { Incorporating the } \\
\text { assumptions of the } \\
\text { Triple Bottom Line }\end{array}$ & $\begin{array}{l}\text { 1. Strong } \\
\text { commitment to } \\
\text { meet }\end{array}$ & $\begin{array}{l}\text { 1. Strong commitment } \\
\text { to meet the } \\
\text { requirements of the }\end{array}$ & $\begin{array}{l}1 . \quad \text { Strong } \\
\text { commitment to meet } \\
\text { the requirements of }\end{array}$ & $\begin{array}{l}1 . \quad \text { Strong } \\
\text { commitment to meet } \\
\text { the requirements of the }\end{array}$ \\
\hline
\end{tabular}




\begin{tabular}{|c|c|c|c|c|}
\hline $\begin{array}{l}\text { (economic, social and } \\
\text { environmental } \\
\text { factors) into the } \\
\text { business model }\end{array}$ & $\begin{array}{l}\text { requirements of } \\
\text { the law in the field } \\
\text { of environment } \\
\text { protection. } \\
\text { 2. Strong } \\
\text { commitment to } \\
\text { create value for } \\
\text { shareholders. } \\
\text { 3. Strong } \\
\text { commitment to } \\
\text { respect workers' } \\
\text { rights. }\end{array}$ & $\begin{array}{l}\text { law in the field of } \\
\text { environment } \\
\text { protection } \\
\text { energy law. } \\
\text { 2. Strong commitment } \\
\text { to create value for } \\
\text { shareholders and } \\
\text { other stakeholders, } \\
\text { in particular the } \\
\text { partners in the } \\
\text { network of } \\
\text { companies linked by } \\
\text { capital. } \\
\text { 3. Strong commitment } \\
\text { to respect workers' } \\
\text { rights. }\end{array}$ & $\begin{array}{l}\text { the law in the field of } \\
\text { environment } \\
\text { protection and } \\
\text { energy law. }\end{array}$ & $\begin{array}{l}\text { law in the field of } \\
\text { environment protection } \\
\text { and energy law. }\end{array}$ \\
\hline $\begin{array}{l}\text { Identifying the needs } \\
\text { of stakeholders }\end{array}$ & $\begin{array}{l}\text { Commitment to } \\
\text { analyze the needs of } \\
\text { stakeholders and } \\
\text { respect their needs. }\end{array}$ & $\begin{array}{l}\text { Strong commitment to } \\
\text { analyze the needs of } \\
\text { stakeholders and } \\
\text { respect their needs. }\end{array}$ & $\begin{array}{l}\text { Strong commitment } \\
\text { to analyze the needs } \\
\text { of stakeholders and } \\
\text { respect their needs. }\end{array}$ & $\begin{array}{l}\text { Strong commitment to } \\
\text { conduct a dialogue and } \\
\text { analyze the needs of } \\
\text { stakeholders and } \\
\text { respect their needs. }\end{array}$ \\
\hline $\begin{array}{lr}\text { Identifying } & \text { the } \\
\text { principles } & \text { of } \\
\text { Corporate } & \\
\text { Governance } & \\
\text { appropriate for } \\
\text { companies in the } \\
\text { early stage of } \\
\text { development }\end{array}$ & $\begin{array}{l}\text { Commitment to } \\
\text { pursue the objectives } \\
\text { of the information } \\
\text { policy arising from } \\
\text { the regulations of the } \\
\text { New Connect } \\
\text { Alternative Market. }\end{array}$ & $\begin{array}{l}\text { Commitment to pursue } \\
\text { the objectives of the } \\
\text { information policy } \\
\text { arising from the } \\
\text { regulations of the New } \\
\text { Connect Alternative } \\
\text { Market. }\end{array}$ & $\begin{array}{l}\text { Commitment to } \\
\text { pursue the objectives } \\
\text { of the information } \\
\text { policy arising from } \\
\text { the regulations of } \\
\text { the New Connect } \\
\text { Alternative Market. }\end{array}$ & $\begin{array}{l}\text { Commitment to pursue } \\
\text { the objectives of the } \\
\text { information policy } \\
\text { arising from the } \\
\text { regulations of the New } \\
\text { Connect Alternative } \\
\text { Market. }\end{array}$ \\
\hline
\end{tabular}

The findings indicate that companies from the sector of renewable energy sources, in order to survive, use different ways to make their activity flexible, due to very high changeability and uncertainty resulting from the unstable law in the field of renewable energy sources. By using strategic options incorporated into the business model, applying the principles of balancing goals towards different groups of stakeholders, applying the principles of corporate governance based on the capital market regulations and meeting the economic, environmental and social objectives, they retain the ability to survive and even develop. At the same time they test strategic hypotheses based on potential changes in both the business model and development strategies. They take notice of the parameters dynamising and stabilizing a business model, developing their ability to survive. Not only did the studied companies survive in the unfavourable legal environment in the field of renewable energy sources but they also increased their market capitalization owing to the strategy of implementing necessary changes.

\section{Conclusions}

At the level of conceptualization, parameters dynamising and stabilizing a business model are starting conditions for shaping the determinants of startup survival. These assumptions should be incorporated into the structure of a sustainable business model. At the level of operationalization with the combined use of real options theory and the Lean Startup method, it is reasonable to use the proposed solutions. As a result of the literature review and own research, as well as the application of 
the decision tree method for using real options in designing a business model, the following conclusions can be inferred:

1. The dynamics of the business model, balance and stability of the relationship with the environment create better survival conditions for companies in the early stage of development.

2. Instability and uncertainty determine the need to make business models flexible using different methods.

3. The sustainability of a startup is a key factor characterizing a sustainable business model.

4. Components shaping business models can be modified, using strategic options incorporated into the business model.

5. Dynamic testing of various hypotheses about the business model efficiency is favourable to achieving the sustainability of companies in the early stage of development.

6. Using a decision tree to design business models can be an important element of business analytics supporting the process of monitoring the company's ability to survive.

7. Companies realize that the flexibility of the business model supported by management tools determines the survival of a young business venture.

8. A Sustainable Business Model of startups should be based not so much on the principles of sustainable development but in particular, it should be characterized by the dynamic ability to make changes, adapting to the internal and external environment.

The findings of qualitative research have proved that companies whose business models were designed taking into consideration potential additional real options and who tested them in order to make the business model as effective as planned not only survived but also achieved the expected growth and development. If at the same time they took into account the principles of the Triple Bottom Line, they developed the ability to conduct a dialogue with stakeholders. As a result, they were able to detect all signals about their needs, which led to the implementation of the strategy of listening to the needs of stakeholders and gave another value driver determining the survival of the company.

It was important to the studied companies to implement the assumptions of testing strategic hypotheses dynamically, which supported changes in designed and implemented business models.

Due to delays in implementing the Renewable Energy Sources Act in Poland, some of the studied companies had to modify their business models in order to survive and achieve their development goals. Predicting various real options incorporated into business models enabled the companies to make changes and adapt to the changing external and internal environment.

A sustainable business model of companies in their early stage of development should be based on the abilities to quickly make changes in the business model due to the fact that a large number of alternative options are incorporated into its construction, which can be implemented in a given situation. This approach should be supported by the assumptions of the Lean Startup method, which is based on the strategic pivot management. If possible, a sustainable business model for startups should use, like the large companies do, the Triple Bottom Line assumptions, which may increase the investment attractiveness of these companies due to the potentially fewer risks related to, for example, the dissatisfaction of various stakeholder groups. The presented approach extends previous research on the concept of a sustainable business model by drawing attention to startup companies. They may be included in the literature related to ensuring business sustainability. In a sense, this indicates a noticeable research gap in this area. The author believes that on the basis of quality and bibliographic research, it can be assumed that the hypotheses are proven.

Hypothesis 1. A condition for the survival of the company in the early stage of development is to incorporate the maximum number of real options into the business model and thus 
its ability to dynamically change with the help of the methodology of testing strategic hypothesis is developed.

Hypothesis 2. A necessary condition for the survival of the company in the early stage of development is to use the assumptions of the Triple Bottom Line concept in such a way that they are applied as soon as possible in the life cycle of the organization.

The author has proven the hypotheses based on the above research.

\section{Research limitations and future research}

Key research limitations include the number of studied companies and the scope of their activity. Due to the small number of companies listed on the NewConnect AIM in Warsaw pursuing a strategy of the Triple Bottom Line, the focus was on companies operating in the renewable energy sector. The reason for research on such companies is difficulties in implementing legal regulations under the Renewable Energy Sources Act in Polish conditions, which for a long time was a large uncertainty affecting the development strategies of companies operating in this sector. Uncertainty in legislation resulted in the fact that many of these companies had to change their business models in a dynamic way. The companies that incorporated alternative real options into their business models were able to quickly modify their business models and thus survive the legally unfavourable period of their activity. Such companies were selected as due to their activity, their business model has to be in conformity with the principles of economic performance (requirements of shareholders in relation to activities in the capital market), environmental effectiveness (compliance with environmental regulations - results from the scope of activity in the sector of renewable energy sources), and social requirements (conducting a social dialogue related to the investment interfering with the environment.) In spite of this justification it should be noted that conducting activity in the field of renewable energy sources is specific and subject to numerous regulations, but it is this aspect that triggers uncertainty and that should be neutralized by the flexibility of the business model. Further research on the issue should be focused on assessing the ability of companies in the early stage of development to maintain strategic directions, the effectiveness of the applied business model and financial stability, based on the assumptions of business model flexibility and the principles of balancing economic, social and environmental challenges in the light of the changeability of the external and internal environment.

\section{Author Contributions}

Marek Jabłoński contributes in designing the research, collecting the data and writing the paper.

\section{Conflicts of Interest}

The author declares no conflict of interest.

\section{References}

[1]. Slywotzky, A.J.; Morrison, D.J.; Andelman, B. The Profit Zone: How Strategic Business Design Will Lead You to Tomorrow's Profits. Chichester, England: John Wiley \& Sons Ltd.. 1998.

[2]. Jabłoński, M. Kształtowanie modeli biznesu w procesie kreacji wartości przedsiębiorstw. Difin. 2013, Warszawa. 
[3]. Morris, M.; Schindehutteb M.; Allen J. The entrepreneur's business model: toward a unified perspective. Journal of Business Research. 2005, 58.

[4]. Lüdeke-Freund, F. Business Model Concepts in Corporate Sustainability Contexts, Centre for Sustainability Management (CSM) e.V., Lehrstuhl für Nachhaltigkeitsmanagement Leuphana Universität Lüneburg. Dezember 2009.

[5]. Stubbs, W.; Cocklin, C. Conceptualizing a 'sustainability business model'. Organization \& Environment. 2008, vol. 21, no. 2.

[6]. Schaltegger, S.; Hansen, E. \& Lüdeke-Freund, F. Business Models for Sustainability: Origins, Present Research, and Future Avenues, Organization \& Environment. 2015, online first, 16 September 2015, http://dx.doi.org/10.1177/1086026615599806.

[7]. Schaltegger, S.; Lüdeke-Freund, F. \& Hansen, E. Business cases for sustainability: the role of business model innovation for corporate sustainability, Int. J. Innovation and Sustainable Development. 2012, vol. 6, no. 2.

[8]. Jabłoński, A. Modele zrównoważonego biznesu $w$ budowie długoterminowej wartości przedsiębiorstw z uwzględnieniem ich społecznej odpowiedzialności. Difin. 2013, Warszawa.

[9]. Grudzewski, W.M.; Hejduk, I.K.; Sankowska, A.; Wańtuchowicz, M. Sustainability w biznesie czyli przedsiębiorstwo przyszłości, Zmiana paradygmatów $i$ koncepcji zarządzania, Wydawnictwo Poltext. 2010, Warszawa.

[10]. Dyllick, T. \& Hockerts, K. Beyond the Business Case for Corporate Sustainability, Business Strategy and the Environment. 2002, vol. 11, no. 2.

[11]. Schaltegger, S. \& Burritt, R. Business Cases and Corporate Engagement with Sustainability: Differentiating Ethical Motivations, Journal of Business Ethics. 2015, http://dx. doi.org/10.1007/s10551-015-2938-0.

[12]. Boons, F.; Montalvo, C.; Quist, J. \& Wagner, M. Sustainable innovation, business models and economic performance: an overview, Journal of Cleaner Production. 2013,vol. 45.

[13]. Boons, F. \& Lüdeke-Freund, F. Business models for sustainable innovation: state-of-theart and steps towards a research agenda, Journal of Cleaner Production. 2013, vol. 45.

[14]. Carroll, A. \& Shabana, K. The business case for corporate social responsibility: a review of concepts, research and practice, International Journal of Management Reviews. 2010, vol. 12, no. 1.

[15]. Elkington. J. Cannibals with Forks: The Triple Bottom Line of Twenty-First Century Business. Capstone. 1997, Oxford.

[16]. Schaltegger, S.; Lüdeke-Freund, F.; Hansen E. G. Business Cases for Sustainability and the Role of Business Model Innovation Developing a Conceptual Framework, Centre for Sustainability Management (CSM). 2011, Leuphana Universität Lüneburg.

[17]. Hutchinson, D.; Singh, J.; Walker, K. An assessment of the early stages of a sustainable business model in the Canadian fast food industry. European Business Review. 2012, 24 (6), 519-531. http://scholar . uwindsor.ca/odettepub/53D.

[18]. Bocken, N.M.P.; Rana, P.; Short, S.W. Value mapping for sustainable business thinking, Journal of Industrial and Production Engineering. 2015, 32:1.

[19]. Chruchill N.; Lewis V. The five stages of small business growth. Harvard Business Review. 1983. 61(3).

[20]. Eggers J.; Lehey L.; Churchill N. Stages of small business growth revised. Frontiers of Entrepreneurial Research. 1994. 
[21]. Hanks S.H,; Watson C.J. Tightening the life-cycle construct: A taxonomic study of growth stage configurations in high -technology organizations. Entrepreneurship Theory and Practice, 1993. 18 (2).

[22]. Nanda, R., \& Rhodes-Kropf, M. Investment cycles and startup innovation. Journal of Financial Economics. 2013, 110(2), http://doi.org/10.1016/j.jfineco.2013.07.001.

[23]. Scott M.; Bruce R. Five stages of growth in small business. Long Range Planning. 1987. 20(3).

[24]. Paik, Y., \& Woo, H. Economic Downturn and Financing Innovative Startup Companies. Managerial and Decision Economics. 2013, http://doi.org/10.1002/mde.

[25]. Adizes I. Corporate Lifecycles: How and Why Corporations grow and die and what to do about it. Prentice Hall: Englewood Cliffss. 1989, NJ.

[26]. Blank, S.; Dorf, B. The Startup Owner's Manual. The Step-by-step Guide for Building a Great Company, Hardcover; K\&S Ranch Consulting. 2012, Vol. 1.

[27]. Damodaran, A. Valuing Young, Start-up and Growth Companies: Estimation Issues and Valuation Challenges, Social Science Research Network, Stern School of Business, 2009, New York University.

[28]. Blank, S. Why the Lean Start-Up Changes Everything, Harvard Business Review, 2014.

[29]. Ries, E. The Lean Startup, Penguin Books Ltd. 2011.

[30]. Kulatilaka, N.; Trigeorgis, L. The general flexibility to switch. Financial Management. 1993.

[31]. Copeland, T.; Antikarov, V. Real options: A Proctitioners Guide. 2001, London.

[32]. Trigeorgis, L. Real options - managerial flexibility and strategy resource allocation. The MIT Press. 1996.

[33]. Myers, S.C, Finance theory and financial strategy, MIT Press. 2001, Cambridge, London.

[34]. Adner R.; Levinthal D. Real Options and Real Tradeoffs, Academy of Management Review, 2014, vol 29, no.1.

[35]. Copeland T.; Koller T.; Murrin J. Valuation. Measuring and Managing the Value of Companies. J. Willey. 2000, New York.

[36]. Cyert R.; March J. A Behavioral Theory of the firm, Prentice Hall, Englewood Cliffs, 1958, New Jersey.

[37]. Trigeorgis, L. Real Options: An Overview, [in:] Real Options and Investment under Urcentainty, Mit Press. 2001.

[38]. Kossecki, P. Kreowanie i pomiar wartości przedsiębiorstwa w świecie Internetu. Wydawnictwo Państwowej Wyższej Szkoły Filmowej, Telewizyjnej i Teatralnej. 2011, Łódź.

[39]. Bowman E. H.; Moskowitz G. T. Real Options Analysis and Strategic Decision Making. INFORMS, Organization Science. 2001, Vol. 12, No. 6.

[40]. Patena W. W poszukiwaniu wartości przedsiębiorstwa, Oficyna a Wolters Kluwer business. 2011, Warszawa.

[41]. Savage, G.S. A Real Options Framework for Valuing Start-up Companies, Dissertation Presented for the Degree of Master of Business Administration, The University of Edinburgh, Management School, 2005.

[42]. Kundisch, D.; John, T. Business Model Representation Incorporating Real Options: an Extension of e3-value, Cooperative Computing \& Communication Laboratory, 45th Hawaii International Conference on System Sciences. 2012, IEEE, Computer Society. 
[43]. Wiśniewski, T.; Pawlak, M. Analiza możliwości wykorzystania teorii opcji realnych w formułowaniu strategii przedsiębiorstw, Zeszyty Naukowe Uniwersytetu Szczecińskiego. 2013, nr 761, finanse, rynki finansowe, ubezpieczenia no 60.

[44]. Munoz, C., A real option strategic scorecard decision framework for it project selection, A dissertation submitted in partial fulfillment of the requirements for the degree of Doctor of Philosophy in the Department of Industrial Engineering and Management Systems in the College of Engineering and Computer Science at the University of Central Florida Orlando, 2006, Florida.

[45]. Obłój, K. Strategia organizacji, PWE. 2007. Warszawa.

[46]. Krychowski, C. How can real options help define optimal timing in business model dynamics? An application to the mobile telecommunications industry, XXIII Conférence Internationale de Management Stratégique, Rennes, 26-28 May 2014.

[47]. Rudny, W. Opcje rzeczowe w procesie tworzenia wartości przedsiębiorstwa, Wydawnictwo Akademii Ekonomicznej w Katowicach. 2009.

[48]. Burger-Helmchen, T. Justifying the origin of real options and their difficult evaluation in strategic management. Schmalenbach Business Review. 2007, Vol. 59.

[49]. Creswell J.W. Research Design: Qualitative \& Quantitative and Mixed Methods Approaches, Sage, Thousand Oaks. California 2014.

(C) 2017 by the authors; licensee Preprints, Basel, Switzerland. This article is an open access article distributed under the terms and conditions of the Creative Commons by Attribution (CC-BY) license (http://creativecommons.org/licenses/by/4.0/). 